\title{
Musculoskeletal Disorders and Association with Social Media Use Among University Students at the Quarantine Time Of COVID-19 Outbreak
}

\author{
Amro A*, Albakry S, Jaradat M, Khaleel M, Kharroubi T, Dabbas A and Dwaik R \\ Faculty of Health Professions, Al-Quds University, Hebron, West Bank, Palestine
}

*Corresponding author: Amro A, Faculty of Health Professions, Al-Quds University, Hebron PO Box 94, West Bank, Palestine, Tel: 00970599 889695,E-mail: amro@staff.alquds.edu

Citation: Amro A, Albakry S, Jaradat M, Khaleel M, Kharroubi T, et al. (2020) Musculoskeletal Disorders and Association with Social Media Use Among University Students at the Quarantine Time Of COVID-19 Outbreak. J Physic Med Rehabilita Stu 1(1): 104. doi: 10.15744/2767-4584.1.104

Received Date: May 27, 2020 Accepted Date: February 23, 2021 Published Date: February 25, 2021

\begin{abstract}
Introduction: COVID-19 period was characterized by lockdown and quarantine, the aim of this cross-sectional analytical study is to investigate the effect of COVID-19 quarantine on social media use, and its association with musculoskeletal disorders (MSD) among university students.

Methods: A cross sectional study was conducted among Al-Quds University students. 317 students (average age of 20.34 years) participated in this study. A self-designed questionnaire was used to collect data which was sent to students on social media using a simple random method in almost all academic year phases.

Results: There was a statically significant increase in the following variables during quarantine compared to before $(\mathrm{P}<0.05)$, like hours of using computers or laptop per day (1.93 to 5.37 hours) and in time using Social Media, (2.59 hours to 3.15), the same in the time spent using Smartphones from (3.76 to 7.36 hours). In terms of gender, there was no difference between male and female in time spent on social media for Leisure, Communication, and education $(\mathrm{P}>0.05)$. There was no statistically significant difference in time spent on exercise before and during quarantine with average time before the quarantine of 0.80 hours to 0.7 hours during the quarantine $(\mathrm{P}>0.05)$. There was a statistically significant increase of severity of Musculoskeletal disorders (MSD) as measured by a scale of $0-10$ during the quarantine $(\mathrm{P}<0.05)$ in terms of severity of headache $(2$ to 2,78$)$, neck pain $(2.06$ to 2.80$)$, and back pain $(2.17$ to 3$)$. This increase in the three dominant MSD was positively correlated with the hours of use of laptops, computers, and mobile phones, for communication and education $(\mathrm{P}<0.05)$. Statistically significant negative correlation was found in between night sleeping hours and severity of MSD reported by students $(\mathrm{P}<0.05)$. Age was correlated with less use of social media for leisure and with more exercise $(\mathrm{P}<0.05)$.
\end{abstract}

Conclusion: Quarantine increased the time of use of social media, and in turn increases the prevalence and severity of MSD among university students.

Keywords: Musculoskeletal Problems; Social Media; Computer; Laptop; Mobile Phone; Coronavirus (COVID-19); Quarantine; University Students

\section{Introduction}

On January $30^{\text {th }}, 2020$ Coronavirus (COVID-19) was announced as a global pandemic by the World Health Organization (WHO) (Chen et al, 2020) [1]. Coronavirus has imposed quarantine on over 3 billion people around the world, as a major strategy to decrease the incidence of Coronavirus infection among the majority of countries. This quarantine is associated with changes on the daily activity routine among all sectors of population in general, where less physical activity has become a habit, and more use of social media for different purposes has exceeded all previous limits, since the majority of people are under home quarantine and out of work, or working from home, for those whom their professions allowed that, the same with students, mainly university students who continued their education remotely online.

Over the last years, there was almost a 25\% increase of the number of people suffering from musculoskeletal disorders (MSD) around the world (Borhany, 2019) [2]. MSD could be defined as "conditions comprise more than 150 diagnoses that affect the locomotor system; that is, muscles, bones, joints and associated tissues such as tendons and ligaments, as listed in the International Classification of Diseases" (WHO, 2019) [3]. Musculoskeletal conditions are usually characterized by pain, mobility restrictions, lack of skills and decreased functional ability. It also reduces people's ability to work and cooperate in social roles [3].

Most people with MSD suffer back, neck, and shoulder pain (Obembe et al. 2013) [4]. In addition, musculoskeletal pain is a certain health issue which is not limited to adults only but also in the young people [4]. 
Social media is an "internet-based technology that facilitates the sharing of ideas, thoughts, and information through the building of virtual networks and communities, it gives users quick electronic communication of content, which includes personal information, documents, videos, and photos" (Dollarhide, 2019) [5]. According to Global Web Index (Worldwide), there are more than 3.5 billion social media users around the world. In the last 10 years, social media applications and their usage have been increasing quickly among students, and the effect on student's academic performance varies (Alahmar, 2016) [6] (Kulidtod, Pasagui, 2017) [7]. In addition, it's found that males are more addicted to social media usage than females (Lokithasan et al. 2019) [8]. Nowadays, social media has become increasingly associated with daily living (Scott et al, 2017) [9]. Since social media represents a source of information, leisure time, and communication method, people are expected to have more time spent on social media. The extent of increase of social media use in quarantine time has not been studied before and there is a lack of information about impact of this increase on musculoskeletal problems among the population.

This research is aiming to investigate the extent of increase in the use of social media and its association with spectrum of musculoskeletal complications prevalence, among population of students at Al-Quds University in Palestine, as on top of what other people are doing on social media, they are also doing their online education during this quarantine time.

\section{Methodology}

\section{Sampling and Population}

317 students were selected using a convenient sampling method for this study as it was the easiest and fastest in terms of application, since we had very limited time. Inclusion criteria included university students, males and females, aging between (18-25) years old, and using social media. Students who were not registered at this semester, or not affiliated to Al-Quds university, or not using laptop, computer or mobile were excluded from this study.

\section{Design}

A cross sectional descriptive analytical study was adopted, as it was the best design to answer the research questions within a short period of time. And at the same time, it represents the best design to answer the questions within the era of the quarantine of COVID-19.

\section{Assessment and Tools}

Data collection sheet was developed by the researchers to investigate the research questions and it included 28 questions, which contained personal variables, the general demographics including age, gender, the faculty, and the academic year, and it also contained the duration of social media use including leisure, learning, and communication, duration of electronic devices use including laptop, computer, and mobile phone, duration of sleeping at day and night, , and time spent in exercise before and after quarantine. In addition, students were asked to rate their pain on a scale from 0 to 10 , where zero represents "no pain at all" and 10 represents "the worst pain they have ever experienced", whether it was headache, neck, or back pain. Finally, they were asked to rate themselves in terms of proper posture while using social media.

The data collection took 3 days between April 10th, and April 13th, 2020, during which 317 questionnaires were filled using Google forms as a web-based questionnaire. Questionnaires advertised using different social media tools.

\section{Ethical Approval}

An informed consent was obtained in the first page of the study's questionnaire, and it was written in Arabic, which is the official language in Palestine, it explained the aims of the study. Privacy was guaranteed. Participants were able to withdraw from the questionnaire at any point. No names were obtained through the questionnaire, and all collected data were used for scientific and research purposes.

\section{Results}

Of the three hundred and seventeen participants, 259 (81.7\%) were females, and $58(18.3 \%)$ were males, and the mean age was 20.34 years $(\mathrm{SD}=2.54)$. The majority of participants were from the Faculty of Health Professions $90(28.4 \%)$, and $89(28.1 \%)$ were in their first year, 67(21.1\%) in second year, 69(21.8\%) in third year, and 92(29.0\%) in fourth year or more (Table 1).

\begin{tabular}{|c|c|c|}
\hline & Frequency & Percentage \% \\
\hline \multicolumn{3}{|c|}{ Gender } \\
\hline Male & 58 & 18.3 \\
\hline Female & 259 & 81.7 \\
\hline \multicolumn{3}{|c|}{ Faculty } \\
\hline Health Professions & 90 & 28.4 \\
\hline Others & 64 & 20.2 \\
\hline
\end{tabular}




\begin{tabular}{|c|c|c|}
\hline & Frequency & Percentage \% \\
\hline Arts & 49 & 15.5 \\
\hline Engineering & 24 & 7.6 \\
\hline Medicine & 19 & 6.0 \\
\hline Dentistry & 17 & 5.4 \\
\hline Science and Technology & 15 & 4.7 \\
\hline Law & 13 & 4.1 \\
\hline Pharmacy & 12 & 3.8 \\
\hline Public Health & 5 & 1.6 \\
\hline \multicolumn{3}{|c|}{ Academic Year } \\
\hline First year & 89 & 28.1 \\
\hline Second year & 67 & 21.1 \\
\hline Third year & 69 & 21.8 \\
\hline Fourth or more & 92 & 29.0 \\
\hline
\end{tabular}

As shown in Table 2, there was a statistically significant difference in mean time using social media for leisure, education, and communication per day before and during the Quarantine $(\mathrm{p} \leq 0.05)$, a statistically significant difference in mean time using computer, laptop or mobile phone per day before and during the quarantine $(\mathrm{p} \leq 0.05)$. And there was also no significant difference in average time spent in exercise per day before and during the quarantine $(\mathrm{p}>0.05)$ (Table 2$)$.

\begin{tabular}{|c|c|c|c|c|c|c|}
\hline & $\begin{array}{l}\text { Mean Before } \\
\text { Quarantine }\end{array}$ & $\begin{array}{l}\text { Mean During } \\
\text { Quarantine }\end{array}$ & $\begin{array}{c}\text { Mean } \\
\text { Difference }\end{array}$ & $\begin{array}{c}\text { Std. Deviation } \\
\text { Before Quarantine }\end{array}$ & $\begin{array}{c}\text { Std. Deviation } \\
\text { During Quarantine }\end{array}$ & P-Value \\
\hline $\begin{array}{l}\text { Social media use per } \\
\text { day for leisure }\end{array}$ & 4.3312 & 7.8076 & 3.48 & 2.82911 & 5.18507 & .000 \\
\hline $\begin{array}{l}\text { Social media use per } \\
\text { day for education }\end{array}$ & 1.9825 & 6.0003 & 4.02 & 2.53459 & 3.88552 & .000 \\
\hline $\begin{array}{l}\text { Social media use per } \\
\text { day for communication }\end{array}$ & 2.7870 & 4.2497 & 1.46 & 3.25891 & 4.57042 & .000 \\
\hline $\begin{array}{l}\text { Computer or laptop } \\
\text { use per day }\end{array}$ & 1.9314 & 5.4183 & 3.49 & 2.66689 & 4.31399 & .000 \\
\hline $\begin{array}{l}\text { Mobile phone use per } \\
\text { day }\end{array}$ & 5.5907 & 9.3019 & 3.71 & 4.16335 & 5.21880 & .000 \\
\hline Sleeping hours at night & 7.2104 & 6.7079 & -0.50 & 1.51003 & 3.06907 & .006 \\
\hline Sleeping hours at day & 1.0185 & 2.2717 & 1.25 & 2.13734 & 2.82680 & .000 \\
\hline $\begin{array}{c}\text { Time spent in exercise } \\
\text { per day }\end{array}$ & .8011 & .6987 & -0.10 & 1.39322 & 1.24385 & .230 \\
\hline
\end{tabular}

Table 2: Results of Paired sample T Test for social media and electronic devices use in before and during quarantine

Regarding the prevalence of musculoskeletal disorders (MSD), there was a statistically significant difference of prevalence and complaints of musculoskeletal disorders between before and during quarantine, as measured by Wilcoxon test ( $\mathrm{p} \leq 0.05)$ (Figure 1 ).

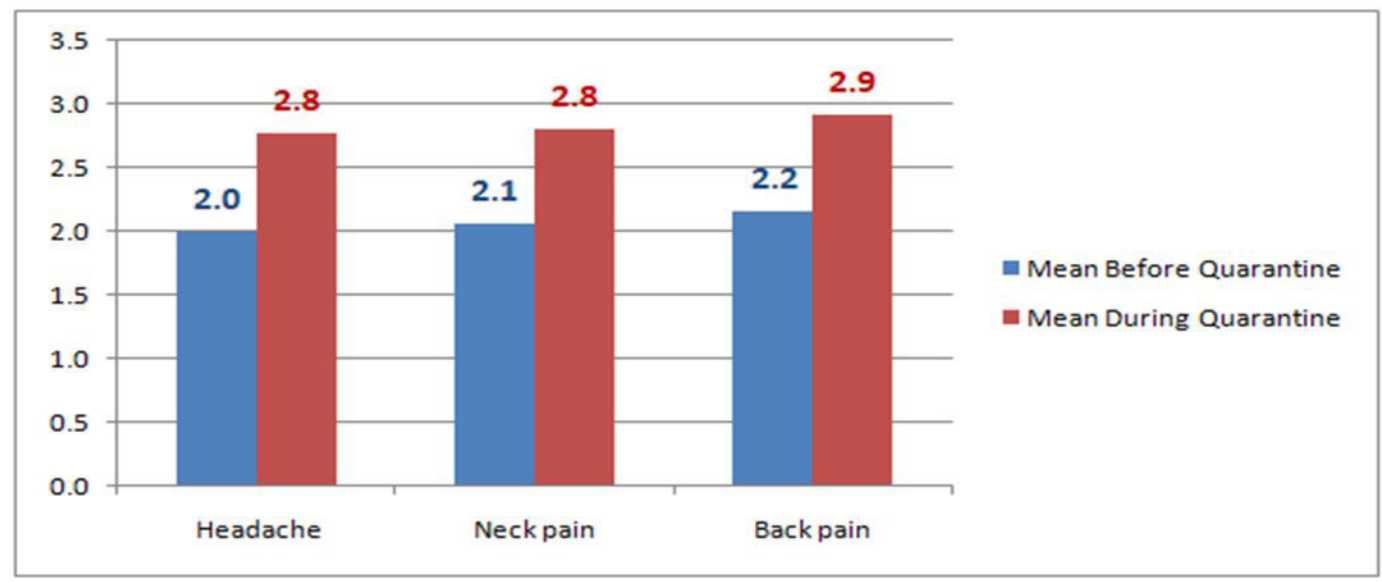

Figure 1: Musculoskeletal Disorders Before and During Quarantine 
In terms of gender differences, Figure 2 shows that there was no significant difference between males and females, in terms of use of social media for Leisure, Communication, and education as measured by Independent Sample T Test. (Figure 2)

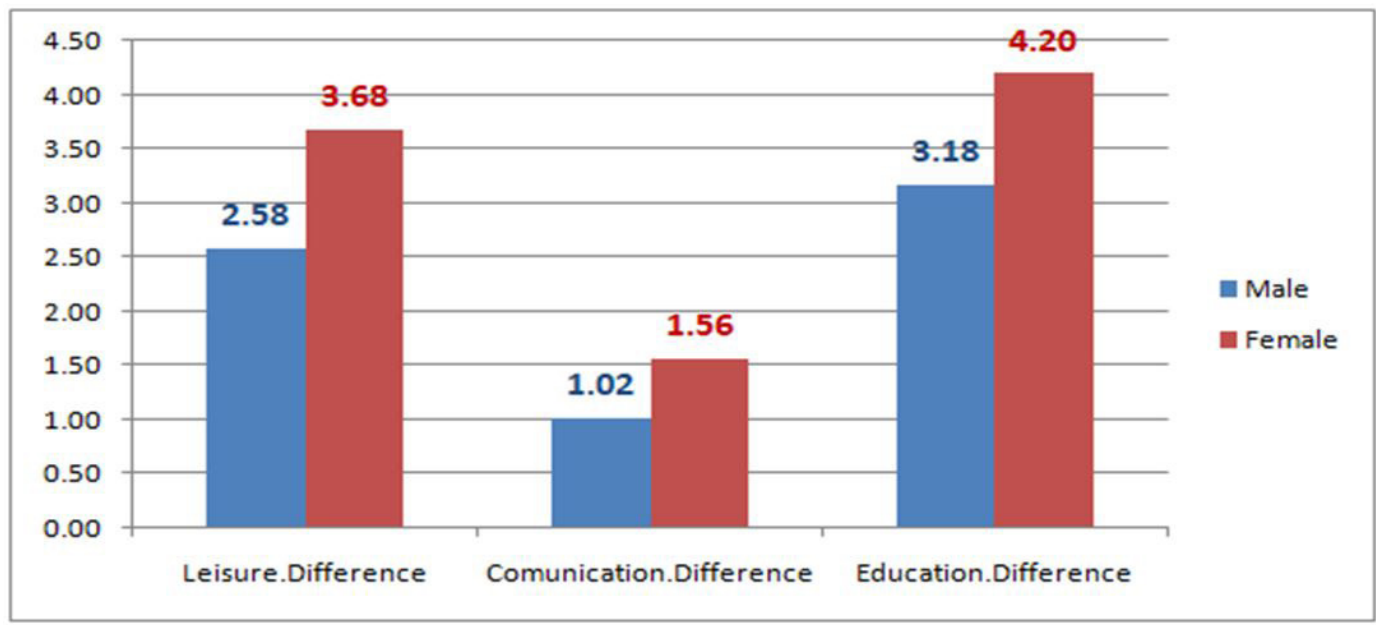

Figure 2: Social media use for Leisure, Communication, and Education

Correlation results as shown in Table 3, shows that there was a statistically significant correlation in between severity of MSD pain and times of use of social media for communication, and education. Negative correlation was found between sleeping hours at the day and the sleeping hours at night $(r=0.407, \mathrm{P}=0.000)$.

\begin{tabular}{|c|c|c|c|c|}
\hline & Age & $\begin{array}{c}\text { During } \\
\text { Quarantine, } \\
\text { Headache }\end{array}$ & $\begin{array}{c}\text { During } \\
\text { Quarantine, } \\
\text { Neck pain }\end{array}$ & $\begin{array}{c}\text { During } \\
\text { Quarantine, } \\
\text { Back pain }\end{array}$ \\
\hline \multirow{2}{*}{ Age } & 1.000 & -0.081 & -0.091 & -0.077 \\
\hline & & 0.151 & 0.105 & 0.170 \\
\hline \multirow{2}{*}{$\begin{array}{l}\text { During Quarantine, } \\
\text { Social media use } \\
\text { per day for leisure }\end{array}$} & -0.090 & 0.110 & 0.079 & 0.065 \\
\hline & 0.110 & 0.051 & 0.159 & 0.248 \\
\hline \multirow{2}{*}{$\begin{array}{c}\text { During } \\
\text { Quarantine, Social } \\
\text { media use per day } \\
\text { for education }\end{array}$} & $-.125^{\star}$ & $.268^{* *}$ & $.297^{* *}$ & $.161^{* *}$ \\
\hline & 0.027 & 0.000 & 0.000 & 0.004 \\
\hline \multirow{2}{*}{$\begin{array}{l}\text { During Quarantine, } \\
\text { Social media } \\
\text { use per day for } \\
\text { communication }\end{array}$} & -0.054 & $.160^{* *}$ & $.210^{* *}$ & $.164^{* *}$ \\
\hline & 0.340 & 0.004 & 0.000 & 0.004 \\
\hline \multirow{2}{*}{$\begin{array}{l}\text { During Quarantine, } \\
\text { Computer or laptop } \\
\text { use per day }\end{array}$} & -0.040 & $.263^{* *}$ & $.284^{* *}$ & $.195^{\star *}$ \\
\hline & 0.476 & 0.000 & 0.000 & 0.001 \\
\hline \multirow{2}{*}{$\begin{array}{c}\text { During Quarantine, } \\
\text { Mobile phone use } \\
\text { per day }\end{array}$} & $-.147^{* *}$ & $.162^{* *}$ & $.139^{*}$ & $.145^{\star *}$ \\
\hline & 0.009 & 0.004 & 0.014 & 0.010 \\
\hline \multirow{2}{*}{$\begin{array}{c}\text { During Quarantine, } \\
\text { Sleeping hours at } \\
\text { night }\end{array}$} & 0.021 & $-.174^{\star *}$ & $-.137^{\star}$ & $-.135^{\star}$ \\
\hline & 0.716 & 0.002 & 0.015 & 0.016 \\
\hline \multirow{2}{*}{$\begin{array}{c}\text { During Quarantine, } \\
\text { Sleeping hours at } \\
\text { day }\end{array}$} & 0.079 & $.154^{* *}$ & 0.095 & 0.108 \\
\hline & 0.162 & 0.006 & 0.093 & 0.055 \\
\hline \multirow{2}{*}{$\begin{array}{l}\text { During Quarantine, } \\
\text { Time spent in } \\
\text { exercise per day }\end{array}$} & $.116^{*}$ & -0.094 & -0.105 & $-.162^{* *}$ \\
\hline & 0.040 & 0.096 & 0.062 & 0.004 \\
\hline
\end{tabular}

Table 3: Correlation between Age, social media use, electronic devices use, sleeping hours, and time spent in exercise and severity of MSD during quarantine

In terms of taking care for a proper posture, it seems that the vast majority is not considering preventive measures in posture when using smart phones nor computers for social media in communication, education or leisure, as only $12.9 \%$ of smart phone users and $15.7 \%$ of computer users consider proper posture recommendations while using social media. This consideration was negatively associated with the severity of MSD (Table 4) while using social media in both laptops and smart phones. 


\begin{tabular}{|c|c|c|c|}
\hline & Headache & Neck pain & Back pain \\
\hline \multirow{2}{*}{ Proper posture while using Computer or Laptop } & $-.117^{*}$ & $-.168^{* *}$ & $-.261^{* *}$ \\
\cline { 2 - 4 } & .038 & .003 & .000 \\
\hline \multirow{2}{*}{ Proper posture while using Mobile phone } & -.067 & $-.143^{*}$ & $-.163^{* *}$ \\
\cline { 2 - 4 } & .233 & .011 & .004 \\
\hline
\end{tabular}

**. Correlation is significant at the 0.01 level (2-tailed)

*. Correlation is significant at the 0.05 level (2-tailed)

Table 4: Correlation between severity of MSD and extent of care for

postural standards while using social media in quarantine

\section{Discussion}

There was a statistically significant increase during quarantine compared to before in using computers, laptops per day (1.93 to 5.37 hours) and in time using Social Media, (2.59 hours to 3.15), the same in the time spent using smart phones from (3.76 to 7.36 hours). This result was expected as first of all the university went into online education during the quarantine, so there was more connection for the students with the smart phones, and computers (both desktops and laptops). On the other hand with the huge amount of knowledge and update about the COVID-19 on social media, it replaced the need for following up of news on other communication tools like TV, as it covers life podcast, and a variety of formal statements and personal experiences, which made people get more addicted to the use of social media, in a time that everyone is feeding his stress through the continuous follow up of the updates of this pandemic that changed the lives of people everywhere in the globe. This confirms the results found by (Cellini et al. 2020) [10] in Italy, which investigated that during lock down people increased the time of using social media.

In terms of gender, there was no difference in between male and female in terms of time spent on social media for leisure, communication, and education $(\mathrm{P}>0.05)$. As we think that both males and females are equally affected by the consequences of the pandemic, which makes them in need for continuous update and also for the use of social media for communication and education, and this also fits with (Jackson et al, 2001) [11] study which indicated that both males and females use social media equally often.

There was no statistically significant difference in time spent on exercise before and during quarantine with average time before the quarantine of 0.80 hours to 0.7 hours during the quarantine $(\mathrm{P}>0.05)$. This could be justified by the fact that sport is a habit and an attitude, that people complains about lack of time for justifying the fact that they do not perform exercise, this result confirms the statements that suggests that exercise is life style rather than luxury of time.

There was a statistically significant increase of severity of Musculoskeletal disorders (MSD) as measured by a scale of 0-10 after the quarantine $(\mathrm{P}<0.05)$ in terms of severity of headache, neck, and back pain. As we think that the excessive time of use of social media is leading to more hours stress on posture, specially that we notice that the vast majority did not care of considering postural recommendations while using social media, which was apparent by the statistically significant correlation between the extent of this consideration and the severity of the MSD, those results support the finding of (Rimba et al. 2019) [12] that improper work posture is related to MSD. At the same time this severity was also affected in a statically positive correlation with the length of use of social media, as in terms of epidemiology, this means the extent of exposure that will lead for further severity of complains, this finding was previously supported by (Woo, 2016) [13].

Statistically significant negative correlation was found in between night sleeping hours and severity of MSD reported by students, as in literature night sleeping had been recommended by (Topping, 2019) [14] as it has relation with stress (Almojali et al. 2017) [15] that itself may affect MSD (Tantawy, 2017) [16].

\section{Limitations}

One of the main limitations of this study that it was conducted in certain period of time "COVID 19 Quarantine" the study would have been more informative if it was performed again after the quarantine where a comparison could have been very valuable.

\section{Conclusion}

Quarantine increased the time of use of social media, which in turn increased the prevalence and severity of MSD among university students. Further research is recommended in the field of proper measures to prevent MSD complications and a consequence of long use of social media, both age and gender had no effect on the association between use of social media and the severity of MSD.

\section{References}

1. Chen P, Mao L, Nassis GP, Harmer P, Ainsworth BE, et al. (2020) Wuhan coronavirus (2019-nCoV): The need to maintain regular physical activity while taking precautions. J Sport Health Sci 9: 103.

2. Borhany T, Shahid E, Siddique WA, Ali H (2018) Musculoskeletal problems in frequent computer and internet users. J Family Med Prim Care 7: 337.

3. World Health Organization (WHO) (2020) Musculoskeletal Conditions. World Health Organization, Geneva, Switzerland.

4. Obembe AO, Johnson OE, Tanimowo TO, Onigbinde AT, Emechete AA (2013) Musculoskeletal pain among undergraduate laptop users in a Nigerian University. J Back Musculoskelet Rehabil, 26: 389-95. 
5. Dollarhide M (2019) Social Media Definition. Investopedia.

6. Alahmar A (2016) The impact of social media on the academic performance of second year medical students at College of Medicine, University of Babylon, Iraq. J Med Allied Sci 6: 77- 83

7. Kulidtod R, Pasagui N (2017) Effects of social networking media to the academic performance of the student. In: Proceedings of the 2nd international conference on educational management and administration (CoEMA 2017). Atlantis Press.

8. Lokithasan K, Simon S, Jasmin NZB, Othman NAB (2019) Male and Female Social Media Influencers: The Impact of Gender on Emerging Adults. Int J 2: 21-30. 9. Scott CF, Bay-Cheng LY, Prince MA, Nochajski TH, Collins RL (2017) Time spent online: Latent profile analyses of emerging adults' social media use. Computers in Human Behavior 75: 311-9.

10. Cellini N, Canale N, Mioni G, Costa S (2020) Changes in sleep pattern, sense of time, and digital media use during COVID-19 lockdown in Italy. J Sleep Res 2020: $10.1111 /$ jsr.13074.

11. Jackson LA, Ervin KS, Gardner PD, Schmitt N (2001) Gender and the Internet: Women communicating and men searching. Sex roles $44: 363-79$.

12. Rimba JT, Naiem F, Rahim MR (2019) Relationship between Work Posture and Musculoskeletal Disorders (Msds) at Processing Workers in PtToarco Jaya, Rantepao City year 2017. Indian J Public Health Res Dev 10: 1025-10.

13. Woo EH, White P, Lai CW (2016) Musculoskeletal impact of the use of various types of electronic devices on university students in Hong Kong: An evaluation by means of self-reported questionnaire. Manual Therapy 26: 47-53.

14. Topping G (2019) Students Are Not Sleeping Enough: Comparing High School Sleep Schedules to College Sleep Schedules A Look into the Importance of Sleep, the Factors Affecting Sufficient Sleep and its Effect on Health and Academic Success Gabrielle Topping. Digital Commons IC.

15. Almojali AI, Almalki SA, Alothman AS, Masuadi EM, Alaqeel MK (2017) The prevalence and association of stress with sleep quality among medical students. J Epidemiology Global Health 7: 169-74.

16. Tantawy SA, Rahman AA, Ameer MA (2017) The relationship between the development of musculoskeletal disorders, body mass index, and academic stress in Bahraini University students. Korean J Pain 30: 126.

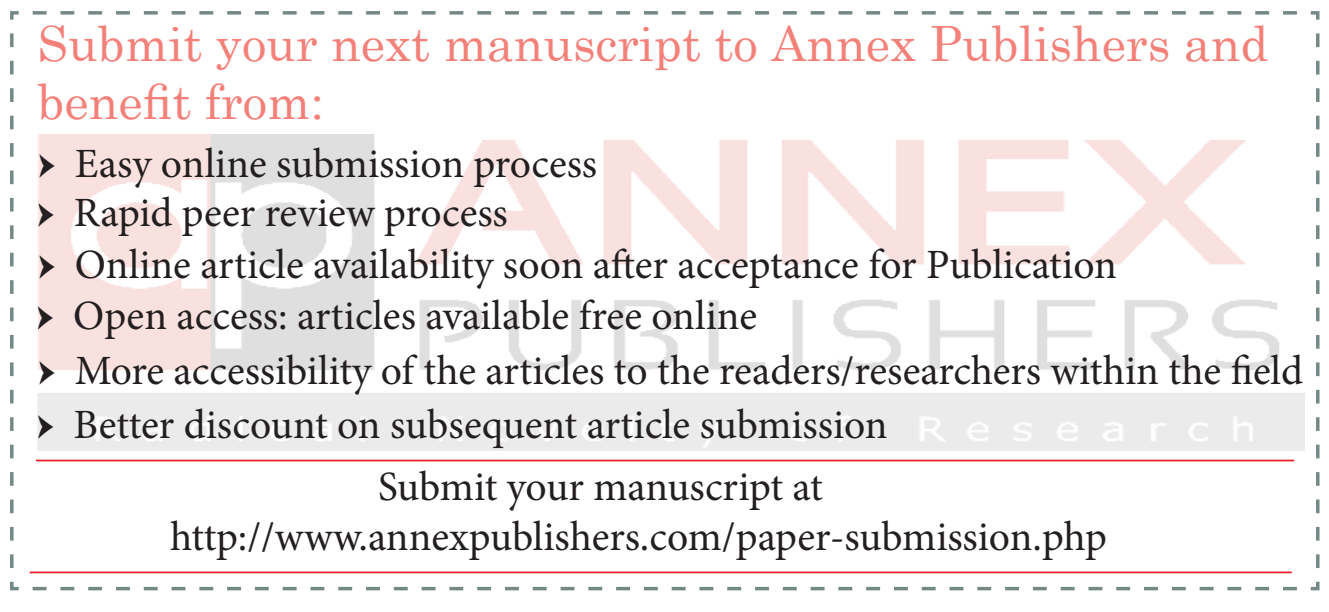

